\title{
DILEMA PELIMPAHAN WEWENANG WALIKOTA DALAM PELAKSANAAN PELAYANAN TERPADU KECAMATAN (PATEN) DI KOTA BANDUNG
}

Novie Indrawati Sagita

Departemen Ilmu Pemerintahan FISIP Universitas Padjadjaran

Email: novie.indrawati.sagita@unpad.ac.id

\section{ARTIKEL INFO}

ABSTRACT

Keywords: Delegation of Authority, Integrated Services, Districts, Licensing Services, Innovation
Regional autonomy provides broad and tangible authority to local governments to carry out public services. Acceleration of improving service quality requires creativity and innovation so that services can be carried out effectively and efficiently. The government wants public services to be closer to the community, so that the sub-district becomes the spearhead of services provided by the regional government. A set of regulations issued by the government that gives authority to the sub-district to carry out licensing and non-licensing services. One of the policies issued is the integrated subdistrict administrative service (PATEN), this policy is reinforced by the issuance of Bandung City Regulation No. 185/2015 concerning the delegation of mayor's authority to the sub-district and village heads. PATENT policy requires the sub-district as a node of one-stop integrated services. In practice, there is a dilemma in delegating the authority of the mayor to the sub-district head regarding the implementation of PATENT in the city of Bandung.

Some of the factors that inhibit the implementation of the PATENT include the limits of authority delegated to the sub-district head in the licensing service is unclear, there are different interpretations that the subdistrict does not need to provide licensing services because Bandung has BPMPTSP besides geographically not too large so that service institutions it can be reached by the community, there is no incentive / disincentive for the region to implement or not implement integrated administrative services in the sub-district, the sub-district institutional capacity, especially the availability and competency of human resources that are not sufficient to carry out delegated service authority. Suggestions that can be conveyed regarding the implementation of the PATENT policy, must be considered that the delegation of authority should consider the typology of sub-districts based on the scale, type of service, impact and level of responsibility of the services provided.

\section{PENDAHULUAN}

Pelayanan publik sudah menjadi tugas dalam penyelenggaraan pemerintahan guna memenuhi kebutuhan masyarakat baik berupa barang maupun jasa, yang pelaksanaannya mengacu pada peraturan perundang-undangan. Sesuai dengan semangat otonomi daerah, sebagaimana diamanatkan dalam UU Pemerintahan Daerah (UU No. 22 Tahun 1999 jo UU No. 32 Tahun 2004 jo UU No. 23 Tahun 2014), maka tiap-tiap daerah dapat melaksanakan pembangunan dan pelayanan publik sesuai dengan karakteristik masyarakat, potensi dan kebutuhan daerah masing-masing. Melalui pelaksanaan otonomi daerah, diharapkan pemerintah daerah mampu melakukan inovasi sehingga dapat memberikan dampak bagi peningkatan kualitas pelayanan kepada masyarakat.

Jauh sebelum reformasi bergulir, pelayanan publik yang dilaksanakan pemerintah daerah dinilai belum cukup memuaskan masyarakat. Bentuk-bentuk ketidakpuasan tersebut dinyatakan dalam opini masyarakat yag disuarakan melalui media massa maupun media sosial. Pendapat masyarakat sebagian besar menyatakan bahwa pelayanan pemerintah daerah dianggap kurang responsif dalam menanggapi keluhan, aspirasi dan saran dari masyarakat, prosedur pelayanan yang kurang informatif, pelayanan yang kurang aksesibel (karena tempat pelayanan yang jauh dan terpisah-pisah sehingga sulit 
dijangkau masyarakat), pelayanan yang terlalu birokratis, khususnya pelayanan perijinan dilaksanakan sering kali memakan waktu yang lama karena harus melalui proses di berbagai instansi dan tingkatan,SDM aparatur yang tidak profesional, hingga sikap petugas pelayanan yang kurang ramah. Disamping ketidakpuasan masyarakat tersebut, masalah penyelenggaraan pelayanan publik juga disebabkan oleh kurangnya koordinasi dan tumpang tindih kewenangan akibat perbedaan persepsi diantara instansi penyelenggaraan pelayanan. Berbagai permasalahan pelayanan publik yang diselenggarakan pemerintah daerah pun kemudian dinilai tidak efisien. Oleh karena itu, pemerintah pusat berupaya memperbaiki penyelenggaraan pelayanan publik di daerah dianggap yang responsif sesuai kondisi yang diharapkan masyarakat.

Perbaikan pelayanan tersebut diupayakan melalui kebijakan reformasi birokrasi yang menghadirkan dinamika penyelenggaraan pemerintahan daerah berdasarkan prinsip tata kelola pemerintahan yang baik, dengan lebih memperhatikan kebutuhan dan tuntutan masyarakat. Pemerintah daerah pun dituntut menciptakan inovasi-inovasi dalam rangka peningkatan kualitas pelayanan publik. Untuk mendukung peningkatan kualitas pelayanan tersebut, Pemerintah mengeluarkan kebijakan tindak lanjut undang-undang pelayanan publik, diantaranya menerbitkan Permendagri Nomor 24 Tahun 2006 tentang Pedoman Penyelenggaraan Pelayanan Terpadu Satu Pintu dan Permendagri Nomor 4 Tahun 2010 tentang Pedoman Pelayanan Administrasi Terpadu Kecamatan (PATEN). Pelayanan terpadu satu pintu dan PATEN merupakan paket kebijakan sistem pelayanan terpadu sebagai inovasi manajemen pemerintahan dalam rangka mempermudah dan mempercepat pelayanan kepada masyarakat.

Kota Bandung melalui kepemimpinan Ridwan Kamil dan Oded M.Danial sebagai Walikota dan Wakil Walikota Bandung menerapkan 3 (tiga) pilar penyelenggaraan pemerintahan yakni inovasi, desentralisasi, dan kolaborasi. Melalui penerapan tiga pilar tersebut, salah satu diantaranya adalah melimpahkan sebagian kewenangan walikota kepada kecamatan. Tiga pilar ini merupakan pendukung bagi kelancaran terlaksananya penyelenggaraan pelayanan terpadu terutama di kecamatan di Kota Bandung. Hanya saja meskipun permendagri dan tiga pilar pemerintahan yang digagas Ridwan Kamil dan Oded M.Danial sudah ditetapkan, namun penyelenggaraan PATEN di Kota Bandung tidak terdengar gaungnya. Berdasarkan uraian tersebut diatas, maka pada penelitian ini berusaha mengetahui tentang dilema pelimpahan kewenangan walikota dalam pelaksanaan PATEN di Kota Bandung serta faktor-faktor yang mempengaruhi terhambatnya pelaksanaan PATEN tersebut.

\section{TELAAH PUSTAKA}

Moenir (1995:7) menyatakan bahwa : "pelayanan publik atau pelayanan umum adalah suatu usaha yang dilakukan kelompok atau seseorang atau birokrasi untuk memberikan bantuan kepada masyarakat dalam rangka mencapai suatu tujuan tertentu".Kegiatan pelayanan publik diselenggarakan oleh instansi pemerintah. Instansi pemerintah merupakan sebutan kolektif meliputi satuan kerja atau satuan orang kementrian, departemen, lembaga, pemerintahan non departemen, kesekertariatan lembaga tertinggi dan tinggi negara, dan instansi pemerintah lainnya, baik pusat maupun daerah termasuk Badan Usaha Milik Daerah. Penerima pelayanan publik adalah orang, masyarakat, instansi pemerintah dan badan hukum. Sedangkan, kegiatan pelayanan publik atau disebut juga dengan pelayanan umum, yang biasanya menempel di tubuh lembaga pemerintahan dinilai kurang dapat memenuhi tugasnya sesuai dengan harapan masyarakat. Dalam proses kegiatan pelayanan publik terdapat beberapa faktor atau unsur yang mendukung jalannya kegiatan, antara lain : 1). Sistem, prosedur dan metode yaitu di dalam pelayanan publik perlu adanya sistem informasi , prosedur dan metode yang mendukung kelancaran dalam memberikan pelayanan, 2). Personil, terutama ditekankan pada perilaku aparatur; dalam pelayanan publik aparatur pemerintah selaku personil pelayanan harus profesional, disiplin dan terbuka terhadap kritik dari pelanggan atau masyarakat., 3). Sarana dan prasarana, dalam pelayanan publik diperlukan peralatan dan ruang kerja serta fasilitas pelayanan publik. Misalnya ruang tunggu, tempat parker yang memadai, dan 4). Masyarakat sebagai pelanggan. Masyarakat sebagai pelanggan lauyanan publik sangatlah heterogen baik tingkat pendidikan maupun perilakunya (Moenir, 1995:8).

Secara teoritis, tujuan pelayanan publik pada dasarnya adalah memuaskan masyarakat. Namun kepuasan masyarakat seringkali menjadi kesulitan dan tantangan, karena menurut Arnaboldi, et al (2015: 20-21), sistem manajemen kinerja dalam pelayanan publik bersifat sangat kaku, meski 
nyatanya tidak mampu menghilangkan masalah pelayanan yang terletak pada rendahnya moral aparatur. Ochojski dan Baron (2015: 174) berpendapat bahwa manajemen kinerja layanan publik saat ini menuntut pejabat dan aparatur pemerintah berfikir inovatif. Kunci dari terbangunnya inovasi dalam layanan publik yang baru yakni adanya kepemimpinan yang visioner, mental kewirausahaan, kerangka pengaturan yang sehat, pendanaan pemerintah yang cukup, dan jaringan kolaborasi, sehingga menjadi solusi dalam mencapai pergeseran kecepatan penyampaian layanan dan peningkatan kualitas layanan kepada warga masyarakat.

Pelaksanaan otonomi daerah di Indonesia menitikberatkan pada level Kabupaten/Kota dengan pertimbangan untuk lebih mendekatkan pelayanan kepada masyarakat. Penekanan utama otonomi daerah disebabkan karena masalah tingkat kompleksitas wilayah (kabupaten/kota), besarnya jumlah penduduk, dan luasnya cakupan (converge) pelayanan, (misalnya jarak yang ditempuh masyarakat dan aksesibilitas masyarakat terhadap pelayanan pemerintah kabupaten/kota.

Selama berlangsungnya penyelenggaraan otonomi daerah, terdapat dua pendekatan pembangunan pelayanan. Pelaksanaan otonomi daerah, yang mana pemerintah selama ini cenderung melaksanakan pendekatan sektoral, gagal menjadikan kecamatan sebagai ujung tombak strategi pemerintahan. Oleh karena itu, implementasi kebijakan otonomi daerah telah mendorong terjadinya perubahan, baik secara struktural, fungsional maupun kultural dalam tatanan penyelenggaraan pemerintahan daerah. Salah satu perubahan yang sangat esensial yaitu menyangkut kedudukan, tugas pokok dan fungsi kecamatan yang sebelumnya merupakan perangkat wilayah dalam kerangka asas dekonsentrasi, berubah statusnya menjadi perangkat daerah dalam kerangka asas desentralisasi. Sebagai perangkat daerah, camat dalam menjalankan tugasnya mendapat pelimpahan kewenangan dari dan bertanggung jawab kepada Bupati/Walikota (Mardani, 2011: 548).

Dasar Hukum Pelimpahan sebagian urusan walikota kepada camat, adalah UU Nomor 23 Tahun 2014 Pasal 221 yang menyebutkan bahwa Daerah Kabupaten/Kota membentuk kecamatan dalam rangka meningkatkan koordinasi penyelenggaraan pemerintahan, pelayanan publik dan pemberdayaan masyarakat desa/Kelurahan. kecamatan di bentuk dalam rangka meningkatkan koordinasi penyelenggaraan pemerintahan artinya dengan adanya kecamatan, Camat sebagai pimpinan tertinggi di Kecamatan harus dapat dapat mengkoordinasikan semua urusan pemerintahan di Kecamatan, memberikan pelayanan publik di Kecamatan, dan juga melaksanakan pemberdayaan masyarakat Desa/Kelurahan. Kemudian Pasal 226 disebutkan bahwa Camat mendapatkan pelimpahan sebagian kewenangan bupati/walikota untuk melaksanakan sebagian Urusan Pemerintahan yang menjadi kewenangan daerah kabupaten/kota. Kewenangan bupati/walikota dilakukan berdasarkan pemetaan pelayanan publik yang sesuai dengan karakteristik kecamatan dan/atau kebutuhan masyarakat pada Kecamatan yang bersangkutan. Pelimpahan kewenangan bupati/walikota ditetapkan dengan keputusan bupati/walikota berpedoman pada peraturan pemerintah. Berdasarkan UU Nomor 23 Tahun 2014 pula, camat memiliki dua jenis kewenangan yakni kewenangan atributif dan kewenangan delegatif. Substansi kewenangan atributif adalah : 1). Menyelenggaraan urusan pemerintahan umum; 2). Koordinasi pemberdayaan masyarakat; 3). Penyelenggaraan Keamanan dan ketertiban dalam masyarakat; 4). Koordinasi penerapan dan penegakan Perda dan Perkada; 5). Pemeliharaan prasarana dan sarana pelayanan umum; 6). Penyelenggaraan kegiatan pemerintahan yang dilakukan oleh perangkat daerah di Kecamatan; 7). Membina dan mengawasi penyelenggaraan kegiatan Desa/kelurahan; 8). Melaksanakan Urusan Pemerintahan yang menjadi kewenangan Daerah kabupaten/kota yang tidak dilaksanakan oleh unit kerja perangkat daerah kab/kota yang ada di Kecamatan; dan 9). melaksanakan tugas lain sesuai UU.

Sedangkan substansi kewenangan delegatif tergantung jumlah urusan yang limpahkan dari Walikota kepada camat. Berdasarkan Permendagri Nomor 4 tahun 2010, kecamatan melaksanakan pelayanan bidang perijinan dan non perijinan. Percepatan pelaksanaan pelayanan di tingkat kecamatan di atur dalam Permendagri Nomor 4 Tahun 2010 tentang Pedoman Pelayanan Terpadu Kecamatan. Pelayanan Administrasi Terpadu Kecamatan (PATEN) merupakan inovasi manajemen dalam rangka mendekatkan, mempermudah, dan mempercepat pelayanan administrasi perizinan dan/atau non perizinan di tingkat kecamatan, utamanya bagi kecamatan yang letaknya jauh dari Kantor Pemerintah Kabupaten/Kota dan sulit dijangkau karena faktor kondisi geografis dan infrakstruktur jalan yang belum memadai. Disamping peraturan tentang PATEN, berdasarkan Perpres 98 Tahun 2014, 
kecamatan juga diberikan kewenangan untuk melaksanakan penerbitan ijin Usaha Kecil Menengah (UMK).

Adapun maksud penyelenggaraan PATEN adalah mewujudkan kecamatan sebagai pusat pelayanan masyarakat dan menjadi simpul pelayanan bagi Kantor/Badan pelayanan terpadu di kabupaten/kota. PATEN mempunyai tujuan untuk meningkatkan kualitas dan mendekatkan pelayanan kepada masyarakat.

Kecamatan sebagai penyelenggara PATEN harus memenuhi syarat : 1). Substantif, yakni pendelegasian sebagian wewenang Bupati/Walikota kepada Camat. Pendelegasian wewenang meliputi : bidang perizinan dan bidang non perizinan. Pendelegasian sebagian wewenang ditetapkan dengan peraturan Bupati/Walikota. Pendelegasian dimaksud dilakukan dengan memperhatikan efisiensi dan efektivitas penyelenggaraan pelayanan, 2). Administratif. Persyaratan administratif meliputi standar pelayanan seperti jenis pelayanan, persyaratan pelayanan, prosedur pelayanan, pejabat yang bertanggungjawab terhadap pelayanan, waktu dan biaya pelayanan, dan 3). Teknis. Persyaratan teknis meliputi sarana prasarana dan pelaksana teknis. Sarana prasarana yang dimaksud yakni loket/meja pendaftaran, tempat pemrosesan berkas, tempat pembayaran, tempat penyerahan dokumen, tempat pengolahan data dan informasi, tempat penanganan pengaduan, tempat piket, dan ruang tunggu. Sedangkan pelaksana teknis, meliputi : a). pelaksana teknis meliputi petugas informasi; b). petugas loket/penerima berkas, c). petugas operator komputer, d). petugas pemegang kas, dan e). petugas lainnya sesuai kebutuhan. Untuk menunjang efisiensi dan efektifitas penyelenggaraan PATEN, kecamatan dapat menyediakan sistem informasi.

Bupati/walikota menetapkan kecamatan yang telah memenuhi persyaratan sebagai penyelenggara PATEN. Penetapan kecamatan sebagai penyelenggara PATEN dilakukan dengan keputusan Bupati/Walikota. Dalam hal pelaksanaan PATEN, Bupati/Walikota membentuk Tim Teknis PATEN, yang bertugas mengidentifikasi kewenangan Bupati/Walikota yang dapat dilimpahkan kepada camat.

Pejabat penyelenggara PATEN melakukan pengelolaan layanan secara transparan dan akuntabel. Biaya penyelenggaraan PATEN dibebankan pada Anggaran Pendapatan dan Belanja Daerah, merupakan bagian yang tidakterpisahkan dari rencana kerja dan anggaran kecamatan. Dalam hal penyelenggaraan PATEN menghasilkan penerimaan, wajib melakukan penyetoran ke kas daerah.

Bupati/Walikota melakukan pembinaan dan pengawasan terkait penyelenggaraan PATEN, yakni (1) Penyelenggaraan sebagian wewenang Bupati/Walikota yang dilimpahkan; (2) Penyelenggaraan pelayanan yang pasti, mudah, cepat, transparan, dan akuntabel; dan (3) Penyelenggaraan tugas lainnya yang ditugaskan kepada camat. Pembinaan dan pengawasan sebagai mana dimaksud diatas dapat didelegasikan kepada Tim Teknis PATEN. Hasil pembinaan dan pengawasan disampaikan oleh Bupati/Walikota kepada gubernur dengan tembusan kepada menteri cq Direktur Jenderal yang membidangi pemerintahan umum bahwa setiap penerima layanan diberikan kemudahan untuk mendapatkan informasi.

Dalam hal penyelenggaraan PATEN, Masyarakat turut berperan serta secara aktif dalam penyelenggaraan PATEN. Peran serta dapat berupa keikutsertaan dalam penyusunan standar layanan, memberikan masukan dalam proses penyelenggaraan layanan, dan memenuhi semua persyaratan pada saat meminta layanan. Seluruh kecamatan ditetapkan sebagai penyelenggara PATEN selambatlambatnya 5 (lima) tahun sejak ditetapkan Peraturan Menteri ini (Januari 2010). Dengan demikian berdasarkan peraturan, ditetapkan bahwa seluruh kecamatan telah menerapkan PATEN selambatlambatnya pada tahun 2015 .

\section{METODE PENELITIAN}

Penelitian ini menggunakan metode kualitatif yang bersifat deskriptif. Jenis data yang digunakan yaitu data primer yang diperoleh melalui kegiatan Forum Group Discussion (FGD) dan observasi. Sedangkan data sekunder diperoleh melalui pengumpulan informasi-informasi tertulis dari media massa dan dokumentasi/arsip institusi yang diteliti. Seluruh data yang terkumpul kemudian diseleksi dan direduksi, yakni memilih data-data yang relevan dengan masalah penelitian dan membuang data-data yang dianggap tidak sesuai. Selanjutnya, dilakukan intepretasi data dan penarikan kesimpulan. Agar data-data yang diperoleh tersebut teruji validitas dan reliabilitasnya, maka penulis menggunakan teknik triangulasi dan member check. Adapun teknik triangulasi yang 
digunakan adalah triangulasi sumber, data, dan metode. Triangulasi sumber dan data dilakukan dengan tujuan memperoleh kebenaran data dan informasi dengan cara membandingkan antara pernyataan informan satu dengan informan lainnya, serta melakukan member check, untuk mengkonfirmasi kembali apakah persepsi yang ditangkap peneliti sudah sesuai dengan pernyataan informan, serta membandingkan data primer dengan data sekunder. Adapun triangulasi metode dilakukan dengan cara menguji kebenaran data dan informasi dengan cara membandingkan perolehan data dari hasil FGD dengan observasi dan studi pustaka.

\section{HASIL PENELITIAN DAN PEMBAHASAN}

Wilayah Kota Bandung, dibagi atas 30 kecamatan yang pada umumnya memiliki karakter wilayah pemukiman, perdagangan, perkantoran, pendidikan, dan sedikit wilayah pertanian. Karakter wilayah per kecamatan dapat dilihat pada tabel berikut :

Tabel 1. Karakter Wilayah Kecamatan Kota Bandung

\begin{tabular}{|c|c|c|c|c|c|c|}
\hline No & Kecamatan & Karakter V & Wilayah & No & Kecamatan & Karakter Wilayah \\
\hline 1 & $\begin{array}{l}\text { Bandung } \\
\text { Kidul }\end{array}$ & $\begin{array}{l}\text { Pemukiman } \\
\text { perdagangan, } \\
\text { perkantoran }\end{array}$ & sedang, & 16 & Regol & $\begin{array}{l}\text { Pemukiman sedang-tinggi, } \\
\text { perdagangan }\end{array}$ \\
\hline 2 & Andir & Pemukiman & & 17 & $\begin{array}{l}\text { Bandung } \\
\text { Wetan }\end{array}$ & $\begin{array}{l}\text { Pemukiman tinggi, } \\
\text { perdagangan, pertahanan }\end{array}$ \\
\hline 3 & $\begin{array}{l}\text { Ujung } \\
\text { Berung }\end{array}$ & $\begin{array}{l}\text { Pemukiman } \\
\text { kepadatan } \\
\text { pertanian, pend }\end{array}$ & $\begin{array}{l}\text { dengan } \\
\text { rendah, } \\
\text { didikan }\end{array}$ & 18 & Lengkong & $\begin{array}{l}\text { Pemukiman } \\
\text { perdagangan }\end{array}$ \\
\hline 4 & $\begin{array}{l}\text { Sumur } \\
\text { Bandung }\end{array}$ & $\begin{array}{l}\text { Perkantoran } \\
\text { perniagaan }\end{array}$ & dan & 19 & $\begin{array}{l}\text { Bojongloa } \\
\text { Kidul }\end{array}$ & $\begin{array}{l}\text { Pemukiman tinggi, } \\
\text { perdagangan, industri }\end{array}$ \\
\hline 5 & Panyileukan & $\begin{array}{l}\text { Pemukiman } \\
\text { perdagangan, } \\
\text { pendidikan, inc }\end{array}$ & $\begin{array}{l}\text { sedang, } \\
\text { dustri }\end{array}$ & 20 & Buah Batu & $\begin{array}{l}\text { Pemukiman sedang, } \\
\text { perdagangan, perkantoran }\end{array}$ \\
\hline 6 & Cicendo & $\begin{array}{l}\text { Pemukiman } \\
\text { tinggi, perdaga }\end{array}$ & $\begin{array}{l}\text { sedang- } \\
\text { angan }\end{array}$ & 21 & Sukasari & $\begin{array}{lr}\text { Pemukiman } & \text { kepadatan } \\
\text { sedang, } & \text { pendidikan, } \\
\text { perdagangan } & \end{array}$ \\
\hline 7 & Mandalajati & $\begin{array}{l}\text { Pemukiman } \\
\text { kepadatan rend }\end{array}$ & $\begin{array}{l}\text { dengan } \\
\text { dah, RTH }\end{array}$ & 22 & $\begin{array}{l}\text { Astana } \\
\text { Anyar }\end{array}$ & $\begin{array}{l}\text { Pemukiman } \\
\text { perdagangan }\end{array}$ \\
\hline 8 & $\begin{array}{l}\text { Cibeunying } \\
\text { Kidul }\end{array}$ & $\begin{array}{l}\text { Pemukiman } \\
\text { rendah, perkan }\end{array}$ & $\begin{array}{l}\text { sedang- } \\
\text { toran }\end{array}$ & 23 & Rancasari & $\begin{array}{l}\text { Pemukiman } \\
\text { perdagangan }\end{array}$ \\
\hline 9 & Gede Bage & $\begin{array}{l}\text { Pemukiman } \\
\text { perdagangan }\end{array}$ & sedang, & 24 & $\begin{array}{l}\text { Babakan } \\
\text { Ciparay }\end{array}$ & $\begin{array}{l}\text { Pemukiman tinggi, } \\
\text { perdagangan, industri }\end{array}$ \\
\hline 10 & Arcamanik & $\begin{array}{l}\text { Pemukiman } \\
\text { perdagangan }\end{array}$ & sedang, & 25 & Cidadap & $\begin{array}{l}\text { Pemukiman sedang- } \\
\text { rendah, kawasan lindung, } \\
\text { pertahanan keamanan }\end{array}$ \\
\hline 11 & Batununggal & $\begin{array}{l}\text { Pemukiman } \\
\text { perdagangan }\end{array}$ & tinggi, & 26 & $\begin{array}{l}\text { Cibeunying } \\
\text { Kaler }\end{array}$ & $\begin{array}{l}\text { Pemukiman sedang- } \\
\text { rendah, kawasan lindung, }\end{array}$ \\
\hline 12 & Antapani & $\begin{array}{l}\text { Pemukiman } \\
\text { tinggi, perdaga }\end{array}$ & $\begin{array}{l}\text { sedang- } \\
\text { angan, }\end{array}$ & 27 & $\begin{array}{l}\text { Bandung } \\
\text { Kulon }\end{array}$ & $\begin{array}{l}\text { Pemukiman tinggi, } \\
\text { perdagangan, industri }\end{array}$ \\
\hline 13 & Sukajadi & $\begin{array}{l}\text { Pemukiman } \\
\text { sedang, } \\
\text { perdagangan }\end{array}$ & $\begin{array}{l}\text { kepadatan } \\
\text { pendidikan, }\end{array}$ & 28 & $\begin{array}{l}\text { Kiaracondo } \\
\text { ng }\end{array}$ & $\begin{array}{l}\text { Pemukiman tinggi, } \\
\text { perdagangan, industri }\end{array}$ \\
\hline 14 & Coblong & $\begin{array}{l}\text { Pemukiman } \\
\text { rendah, pendid }\end{array}$ & $\begin{array}{l}\text { kepadatan } \\
\text { likan }\end{array}$ & 29 & Cinambo & $\begin{array}{l}\text { Pemukiman sedang, } \\
\text { perdagangan, industri }\end{array}$ \\
\hline 15 & Cibiru & $\begin{array}{l}\text { Pemukiman } \\
\text { rendah, kawasa }\end{array}$ & $\begin{array}{l}\text { kepadatan } \\
\text { an lindung }\end{array}$ & 30 & $\begin{array}{l}\text { Bojongloa } \\
\text { Kaler }\end{array}$ & $\begin{array}{l}\text { Pemukiman tinggi, } \\
\text { perdagangan, industri }\end{array}$ \\
\hline
\end{tabular}

Sumber : RTRW Kota Bandung 2011-2031

Karakteristik wilayah masing-masing kecamatan tersebut tentu saja mempengaruhi bobot pelayanan kecamatan. Wilayah yang terkonsentrasi pada kegiatan komersial/perdagangan, industri dan perkantoran tentu saja memiliki tingkat pelayanan yang jauh lebih tinggi daripada kecamatan yang hanya didominasi oleh wilayah pemukiman, pertanian, dan sarana pendidikan. 
Oleh karena itu, dalam rangka mempermudah pelayanan dan pembangunan wilayah, Walikota Bandung menerapkan prinsip desentralisasi dengan melimpahkan sebagian urusan Walikota Bandung kepada Camat dan Lurah yang ditetapkan melalui Peraturan Walikota Bandung Nomor 1286 Tahun 2014 tentang Pelimpahan Sebagian Urusan Walikota Bandung kepada Camat dan Lurah. Namun, dalam perkembangan arah kebijakan, program dan kegiatan yang perlu disempurnakan agar dapat meningkatkan efektifitas pelayanan kepada masyarakat dan penguatan peran kewilayahan, maka Peraturan Walikota tersebut kemudian dirubah menjadi Peraturan Walikota Bandung Nomor 185 Tahun 2015. Berdasarkan lampiran Peraturan Walikota Bandung Nomor 185 Tahun 2015 tersebut, urusan Walikota yang dilimpahkan kepada camat adalah sebagai berikut :

Tabel 1. Wewenang Walikota Bandung yang dilimpahkan kepada camat

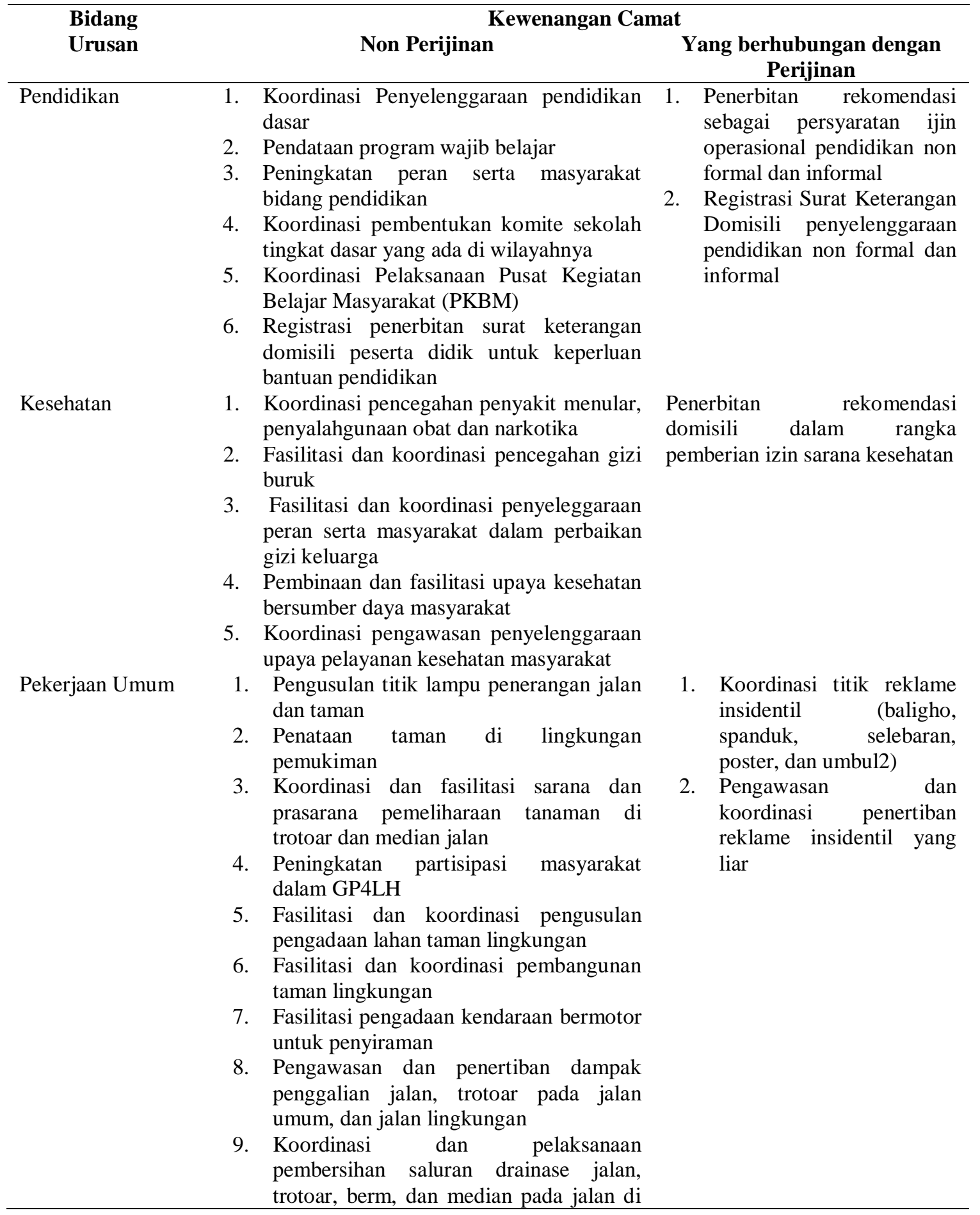




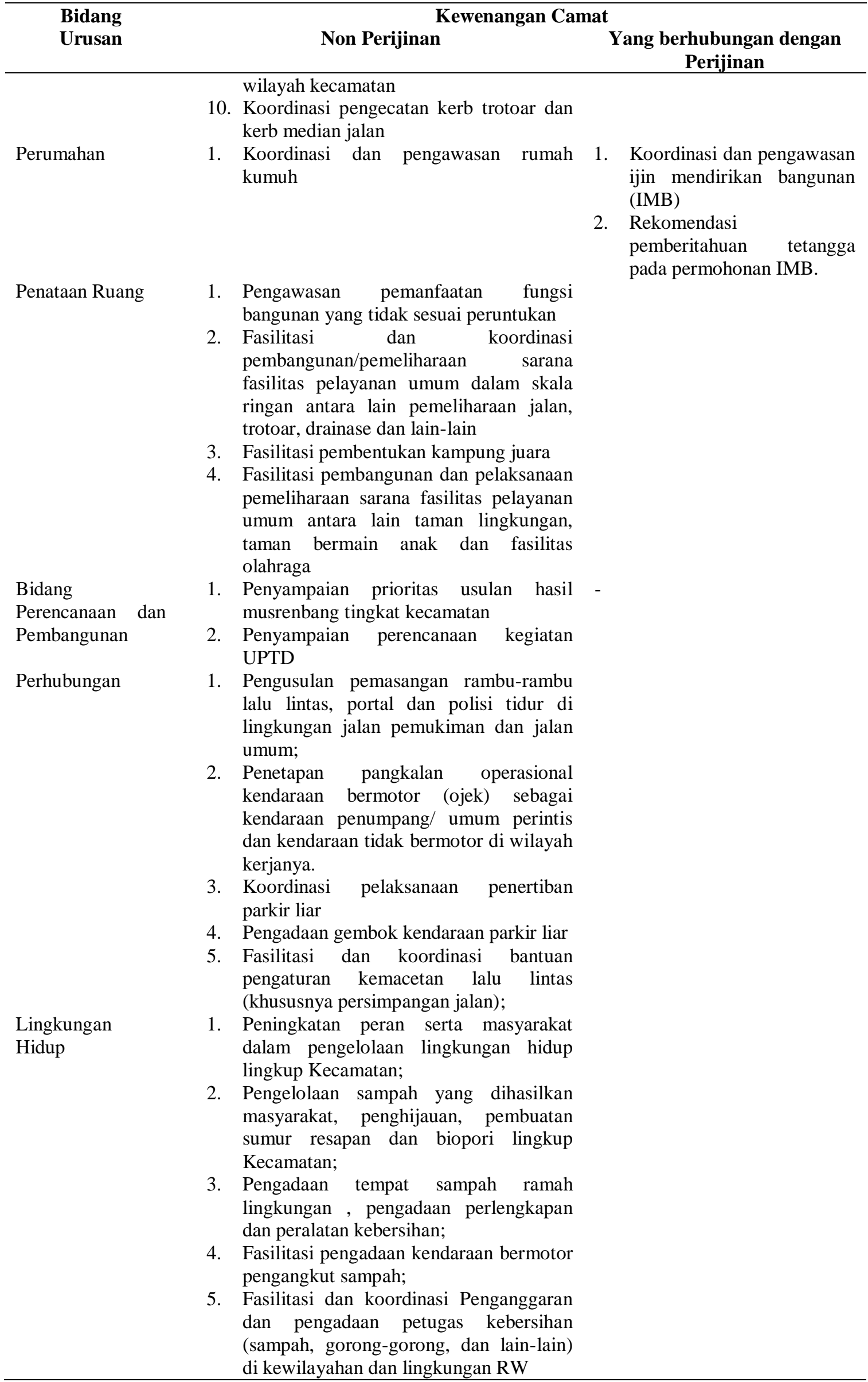




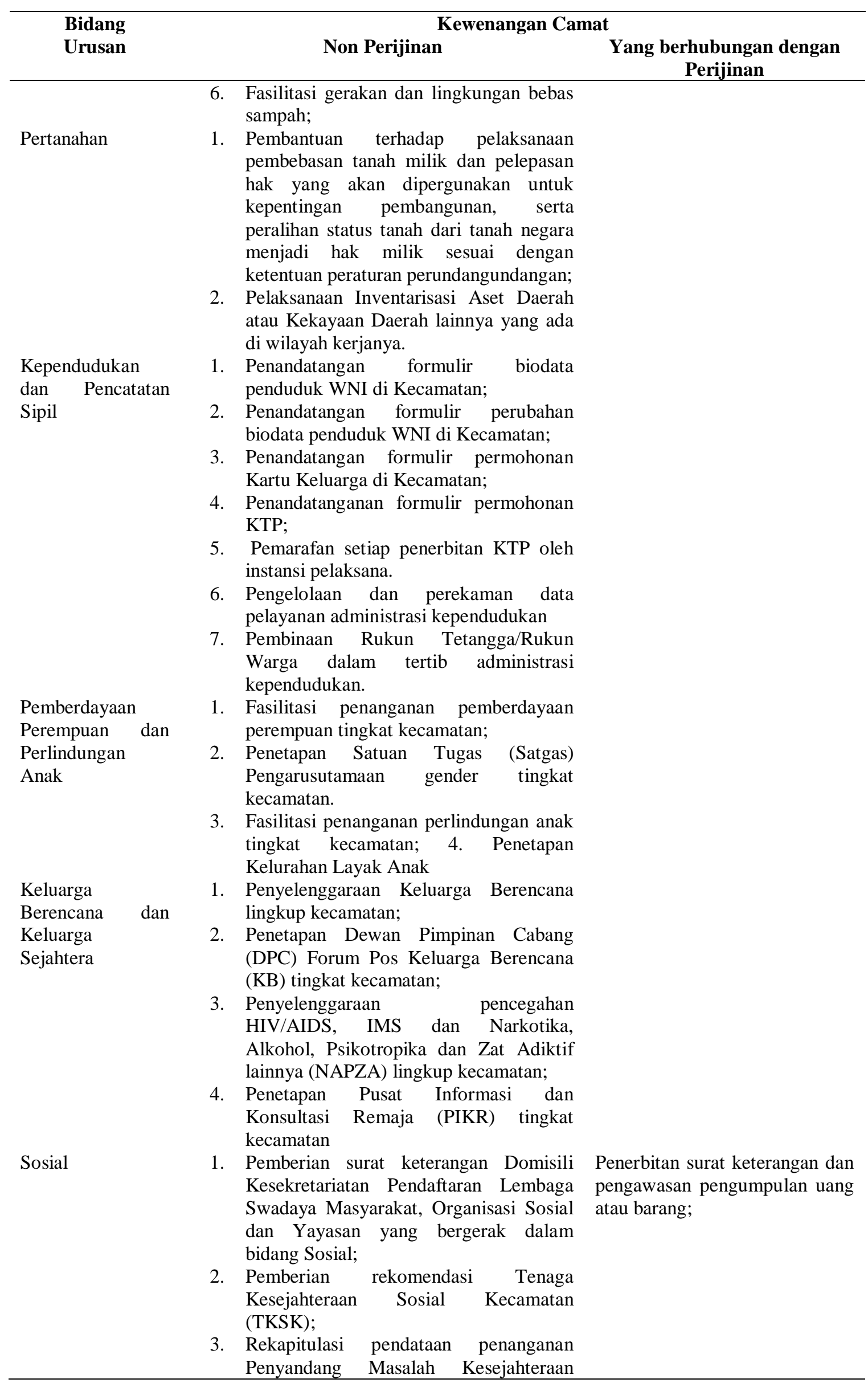




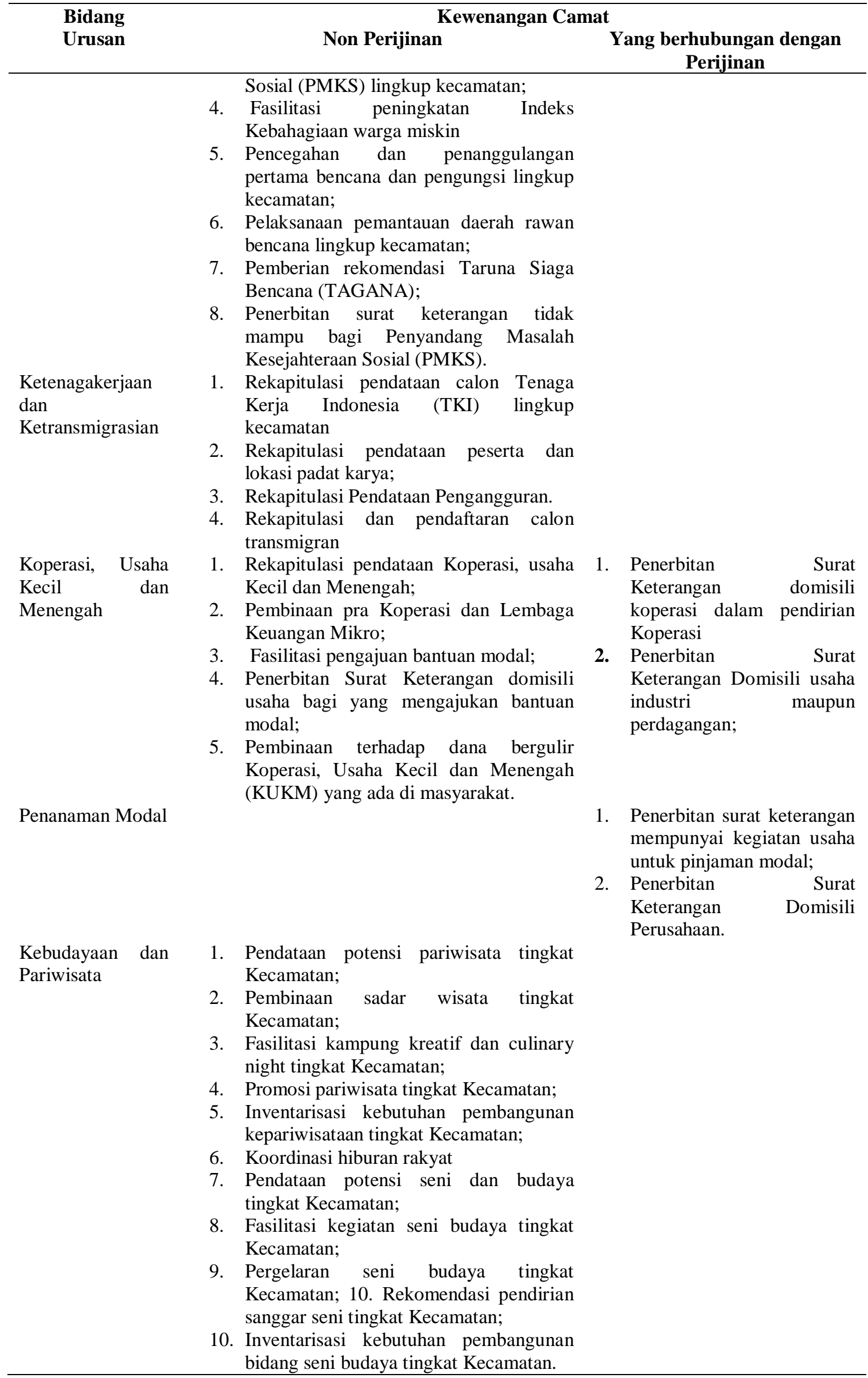




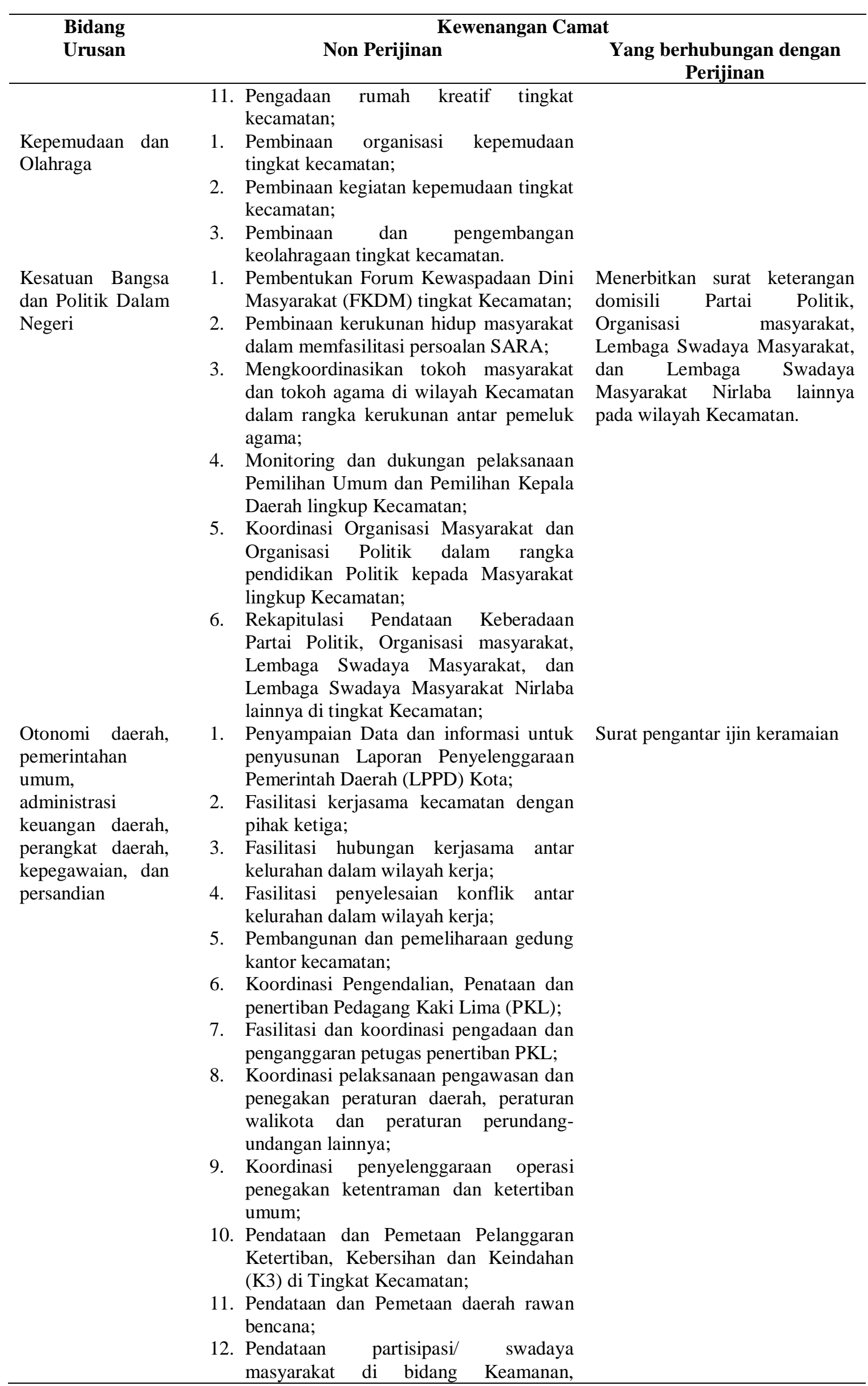




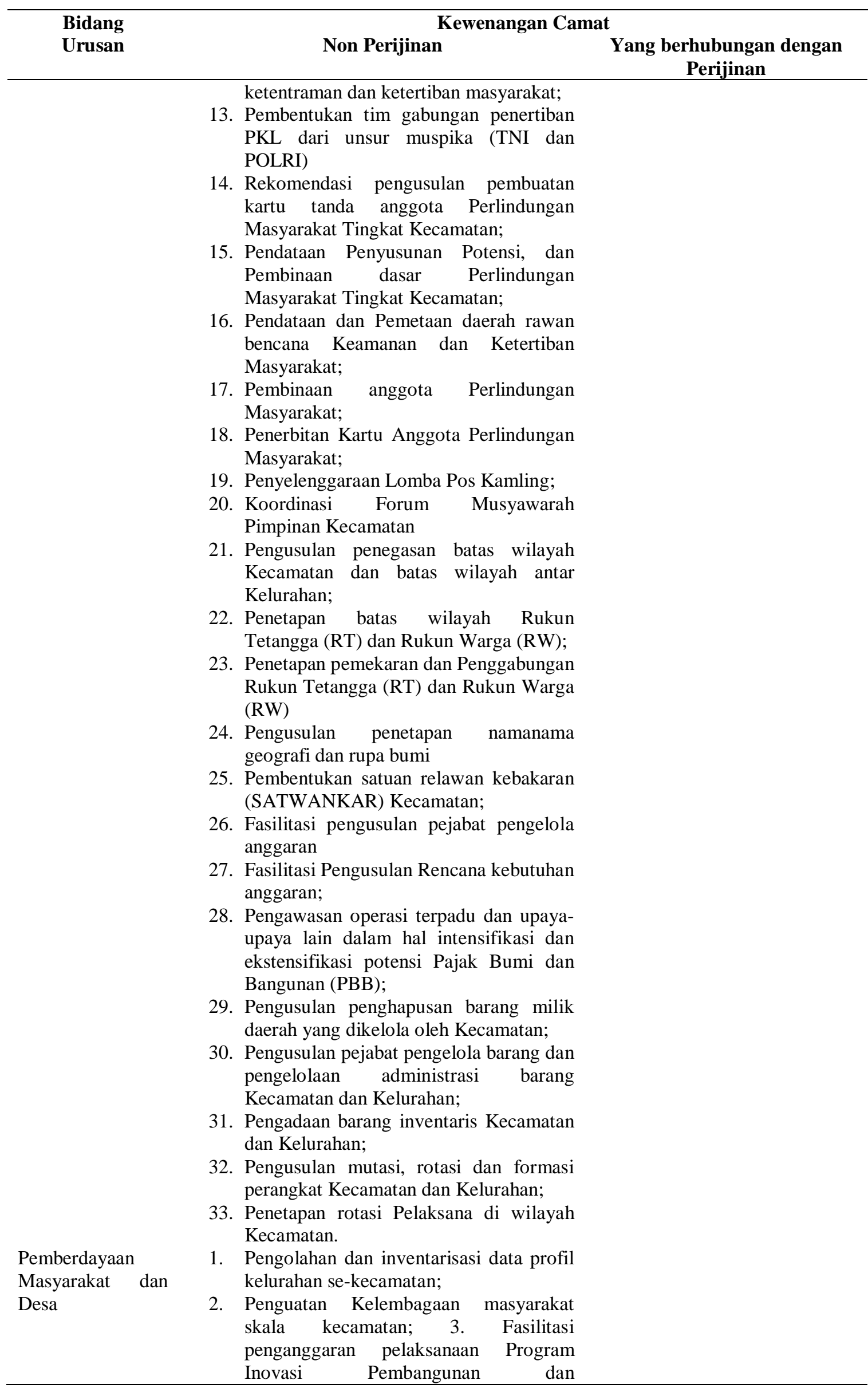




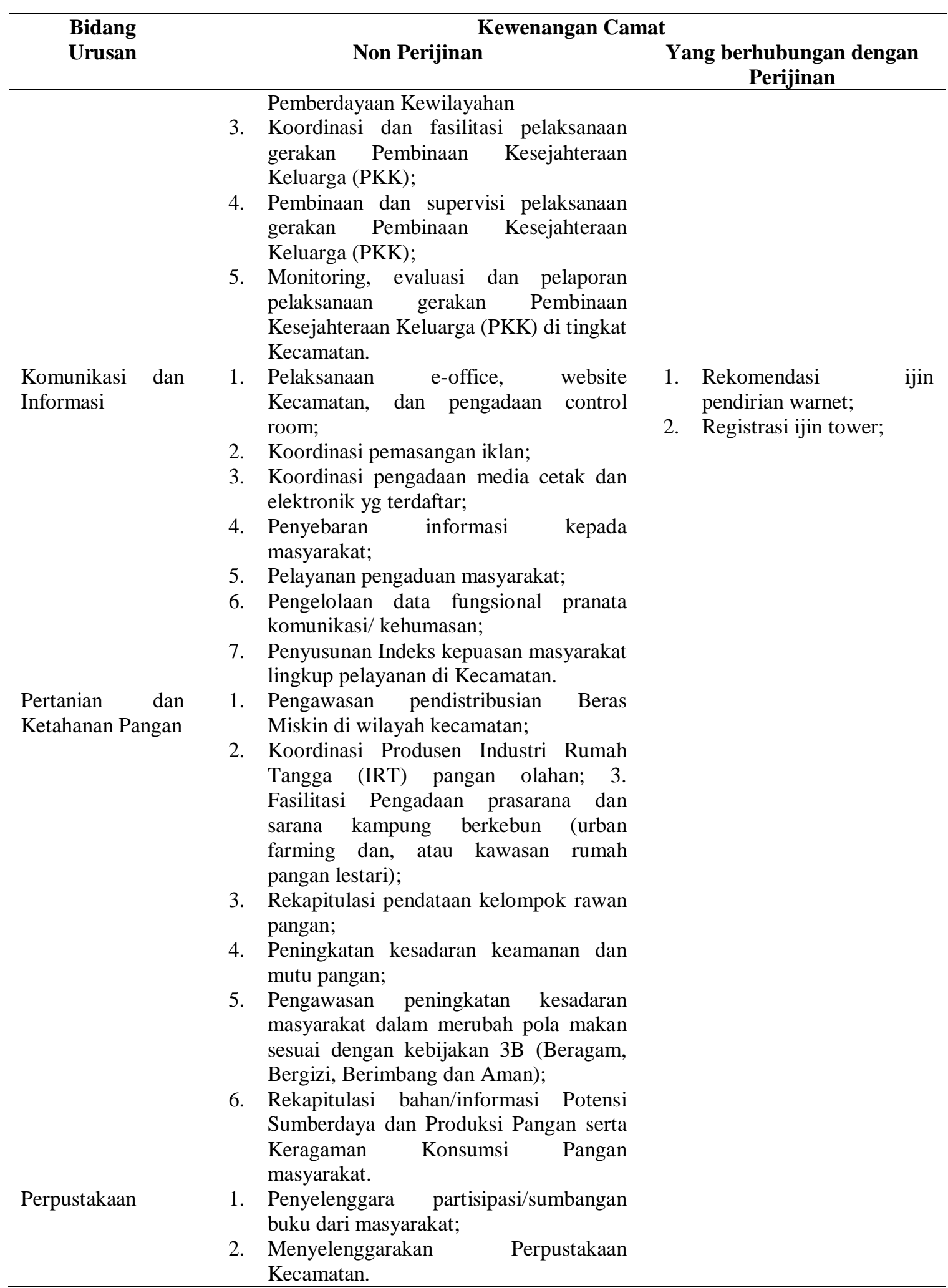

Sumber : Lampiran Perwal Nomor 185 Tahun 2015

Berdasarkan Peraturan Walikota nomor 185 Tahun 2015, sebanyak 24 bidang terdiri atas 145 kewenangan non perijinan dan 16 kewenangan yang berhubungan dengan perijinan, kewenangan Walikota yang dilimpahkan Kepada Kecamatan. Meskipun Peraturan Walikota mengenai pelimpahan kewenangan walikota kepada camat sudah ditetapkan, namun di tingkat implementasinya, pelimpahan kewenangan yang seharusnya disinergikan dengan pelaksanaan PATEN tersebut belum dijalankan. Hal ini disebabkan oleh berbagai faktor, sebagai berikut : 1). Ketidakjelasan substansi kewenangan yang dilimpahkan, yang mana dengan adanya Permendagri Nomor 4 Tahun 2010 tentang pelayanan 
administrasi terpadu kecamatan (PATEN) menghendaki kecamatan menyelenggarakan pelayanan bidang perijinan dan non perijinan. Namun, dalam Perwal 185 Tahun 2015, wewenang camat terkait pelayanan perijinan dan non perijinan belum jelas batas-batas mana yang bisa dilakukan oleh kecamatan dan mana yang tidak bisa dilakukan (atau bidang pelayanan mana uang masih menjadi wewenang perangkat daerah), 2). Lemahnya koordinasi, pembinaan dan pengawasan, evaluasi dan pelaporan oleh Perangkat daerah atas penyelenggaraan urusan yang dilimpahkan kepada camat. Faktor ini merupakan ketidaksempurnaan kedua, yang menunjukkan bahwa mentalitas kerja sama antar aparatur dan perangkat daerah masih rendah, 3). Terkait pelaksanaan PATEN dan Perpres 98 Tahun 2014 tentang IUMK (Ijin Usaha Miro dan Kecil) hingga kini belum diimplementasikan di kecamatan Kota Bandung. Hal ini disebabkan karena masih adanya keraguan akan tumpang tindih kewenangan antara kecamatan dan BPMPTSP terkait ijin usaha mikro dan kecil. Padahal di beberapa Kota pelayanan perijinan tentang IUMK yang dilimpahkan kepada kecamatan sudah dilaksanakan. Di Semarang, IUMK di kecamatan dilaksanakan secara online. Denpasar, penerbitan IUMK di kecamatan sudah dimulai sejak 2015. Sedangkan di Kota Malang penerbitan IUMK dikecamatan tidak perlu disertakan dengan izin HO, 4). Adanya ketidaksepakatan mengenai pelimpahan kewenangan kepada kecamatan yang dianggap bertentangan dengan hadirnya BPMPTSP. Adanya anggapan bahwa pelayanan perijinan di kecamatan tidak perlu dilakukan karena sudah ada BPMPTSP selain itu peraturan pelayanan publik menghendaki pelayanan perijinan dilaksanakan secara terpadu satu pintu, dengan demikian adanya anggapan bahwa pelimpahan kewenangan perijinan di kecamatan bertentangan dengan peraturan BPMPTSP, 5). Aspek kelembagaan kecamatan. Syarat-syarat dapat dilaksanakannya PATEN secara baik, apabila memenuhi syarat yang mencakup tiga aspek yaitu aspek substantif, administratif, dan aspek teknis. Secara substantif, pendelegasian sebagian wewenang Walikota Bandung kepada Camat sudah ada yakni dengan ditetapkannya Peraturan Walikota Bandung Nomor 185 Tahun 2015. Berdasarkan perwal tersebut sebagian besar kewenangan kecamatan bersifat non perijinan, sedangkan kewenangan yang berhubungan dengan perijinan hanya sebatas memberikan fasilitasi atau penerbitan surat sebagai persyaratan permohonan perijinan seperti :a). Penerbitan rekomendasi sebagai persyaratan ijin operasional pendidikan non formal dan informal; b). Registrasi Surat Keterangan Domisili penyelenggaraan pendidikan non formal dan informal; c). Penerbitan rekomendasi domisili dalam rangka pemberian izin sarana kesehatan; d). Koordinasi dan pengawasan ijin mendirikan bangunan (IMB); e). Rekomendasi pemberitahuan tetangga pada permohonan IMB; f). Penerbitan surat keterangan dan pengawasan pengumpulan uang atau barang; g). Penerbitan Surat Keterangan domisili koperasi dalam pendirian Koperasi; h). Penerbitan Surat Keterangan Domisili usaha industri maupun perdagangan; i). Penerbitan surat keterangan mempunyai kegiatan usaha untuk pinjaman modal; j). Penerbitan Surat Keterangan Domisili Perusahaan; k). Menerbitkan surat keterangan domisili Partai Politik, Organisasi masyarakat, Lembaga Swadaya Masyarakat, dan Lembaga Swadaya Masyarakat Nirlaba lainnya pada wilayah Kecamatan; 1). Surat pengantar ijin keramaian; $\mathrm{m})$. Rekomendasi ijin pendirian warnet; dan n). Registrasi ijin tower

Pelayanan penerbitan surat keterangan/rekomendasi/pengantar tersebut sebagai persyaratan mengurus perijinan, sedangkan ijin itu sendiri diterbitkan oleh BPMPTSP atau SKPD terkait. Dalam hal efisiensi dan efektifitas, pengurusan ijin sebagaimana yang dikehendaki dalam Permendagri Nomor 4 Tahun 2010 tentang Pedoman Pelayanan Terpadu Kecamatan, memang belum dilakukan. Selain memang akses masyarakat ke BPMPTSP dan SKPD terkait cukup terjangkau, juga demi kepentingan yang lebih besar, karena keterbatasan kemampuan (jumlah dan kompetensi) aparatur kecamatan tidak memungkinkan untuk menjalankan kewenangan terkait perijinan. Bagaimanapun, pelayanan perijinan bukan hanya sekedar efisiensi pelayanan namun harus mempertimbangkan aspek pengendalian. Sehingga pemberian perijinan merupakan keputusan strategis pejabat yang mengandung konsekuensi hukum, sosial-politik dan lingkungan. Misalnya dari perijinan tersebut memiliki dampak sosial, politik dan ekologis. Kecamatan tentu saja tidak memiliki kapasitas untuk mempertimbangkan dampak-dampak tersebut, sehingga dianggap lebih efektif apabila perijinan tidak diserahkan kepada kecamatan. Dikhawatirkan apabila pelayanan perijinan diserahkan kepada kecamatan akan ada pelanggaran-pelanggaran aturan yang berkaitan. Misalnya pemberian ijin IMB yang berhubungan dengan kebijakan strategis pemanfaatan tata ruang. Dari aspek administratif, kecamatan di Kota Bandung belum semuanya memiliki standar dan prosedur pelayanan (SOP). Tidak adanya SOP tersebut maka kegiatan pelayanan tidak sesuai standar yang akan mempengaruhi kinerja pelayanan. 
Kemudian aspek teknis, sarana dan prasarana penyelenggaraan PATEN seperti tempat piket/front office, loket/meja pendaftaran, tempat pemrosesan berkas, pengolahan data dan informasi, tempat finalisasi proses, ruang tunggu, tempat penyerahan dokumen, tempat pembayaran masing-masing kecamatan kondisinya cukup variatif namun secara umum sudah memenuhi standar minimal penyelenggaraan PATEN. Sarana prasarana ini memang tidak terpisah satu sama lain, namun digabungkan misalnya tempat pemrosesan berkas disatukan dengan ruangan pengolahan data dan informasi. Loket pendaftaran disatukan dengan tempat penyerahan dokumen dan pembayaran.

Dilema pelaksanaan pelimpahan kewenangan walikota kepada kecamatan sebagaimana diatur dalam Perwal Kota Bandung Nomor 185 Tahun 2015 dikarenakan adanya hambatan secara vertikal maupun horizontal jika dikaitkan dengan pelaksanaan PATEN. Secara vertikal, adanya ketidakpatuhan aparatur perangkat daerah terhadap pelaksanaan Permendagri dan perintah walikota untuk menyerahkan sebagian kewenangan kepada kecamatan dengan bersembunyi dibalik alasan bahwa PATEN bertentangan dengan peraturan BPMPTSP, selain itu PATEN tidak perlu dilaksanakan karena pelayanan Kota Bandung ke BPMPTSP dapat diakses masyarakat. Alasan ini sesungguhnya tidak berpijak pada peraturan yang ada, karena berdasarkan peraturan sesungguhnya tidak ada pertentangan antara kewenangan camat dan BPMPTSP terkait pelayanan perijinan dan non perijinan. Pasal 3 Permendagri 4/2010 secara jelas menyebutkan bahwa Kecamatan sebagai pusat pelayanan masyarakat dan menjadi simpul pelayanan bagi kantor/badan pelayanan terpadu di kabupaten/kota. Kemudian, tidak dapat dilaksanakan PATEN karena alasan bahwa Perwal belum jelas dan terperinci mengatur mana yang menjadi kewenangan kecamatan dan mana yang masih jadi kewenangan perangkat daerah, merupakan wujud ketidaksempurnaan unsur-unsur yang menjadi persyaratan bagi terlaksananya manajemen kinerja layanan publik, diantaranya yaitu, adanya ketidak jelasan substansi kewenangan seperti pendapat yang dikemukakan Ochojski dan Baron (2015) dan Moenir (1995) bahwa pengaturan yang sehat menjadi persyaratan dan juga sebagai sistem, prosedur dan metode yang menjadi pedoman bagi aparatur dalam melaksanakan tugasnya sehingga mendukung kelancaran dalam memberikan pelayanan yang baik.

Lemahnya koordinasi, pengawasan dan evaluasi menunjukkan belum adanya sinergitas diantara kecamatan, perangkat daerah, dan Walikota, sebagai bukti adanya hambatan horizontal dalam melaksanakan layanan publik kepada masyarakat. Padahal menurut Arnaboldi, et al (2015: 20-21), penerapan sistem manajemen kinerja tidak akan pernah berhasil mewujudkan pelayanan publik yang inovatif sepanjang para pemimpin tidak mampu menghilangkan masalah pelayanan yang terletak pada rendahnya moral dan integritas aparatur. Oleh karena itu dibutuhkan suatu resolusi dikalangan pimpinan dan aparatur mengenai pelayanan publik yang akan dilakukan agar selalu memperoleh dukungan sebagai dampak dari kepuasan masyarakat.

Bagaimanapun, pelimpahan kewenangan terkait pelayanan administratif terpadu di kecamatan tetap perlu dilaksanakan. Hal ini disebabkan, karena meskipun Kota Bandung bukan wilayah yang luas, namun Kota Bandung belum menjadi kota yang bersahabat terhadap mobilitas ekonomi dan sosial masyarakat yang terganggu akibat kepadatan lalu lintas. Meskipun pelayanan pada BPMPTSP sudah dilaksanakan secara online, nyatanya belum ada jaminan kepastian waktu pelayanan. Masih ada keluhan masyarakat akan lamanya hasil yang diterima untuk jenis-jenis pelayanan tertentu, misalnya saja pelayanan IMB untuk rumah tinggal (bukan wilayah KBU) masih memakan waktu yang lama. Oleh karena itu, untuk beberapa jenis layanan publik yang sekiranya tidak tertangani oleh perangkat daerah dan BPMPTSP dan bukan jenis perijinan yang bersifat strategis (membutuhkan sarana prasarana dan keahlian dalam mempertimbangkan dikabulkannya suatu permohonan perijinan) sebaiknya diserahkan kepada kecamatan. Disini dituntut keberanian dan komitmen antara walikota, pimpinan perangkat daerah dan kecamatan untuk menggali dan berani melakukan inovasi dan menghadirkan metode baru bagi percepatan kualitas layanan publik.

\section{KESIMPULAN DAN SARAN}

Realitas objektif, penyelenggaraan PATEN di kecamatan Kota Bandung masih menghadapi masalah dan tantangan, dan hingga saat ini belum dilaksanakan. Ha ini disebabkan karena : 1). Belum ada rincian detil mengenai kewenangan apa saja yang bisa dilimpahkan, 2). Adanya anggapan bahwa kecamatan tidak perlu menyelenggarakan pelayanan (terutama perijinan), karena di Kota Bandung sudah dibentuk BPMPTSP, 3). Meskipun peraturan PATEN sudah diterbitkan, namun tidak ada 
insentif maupun disinsentif bagi daerah yang melaksanakan, disamping kebijakan PATEN dianggap belum menarik bagi promosi daerah, dan 4). Persepsi aparatur pemerintah Kota Bandung terutama kecamatan yang masih terjebak pada kondisi pelayanan yang bersifat rutin, tanpa inovasi pelayanan masyarakat

Sangat disayangkan kebijakan PATEN belum dilaksanakan di Kota Bandung, padahal kebijakan ini dapat mempercepat dan mempermudah pelayanan kepada masyarakat yang tentu saja dapat mendorong meningkatnya pencapaian kinerja utama kecamatan yaitu IKM (Indeks Kepuasan Masyarakat). Sesungguhnya penerapan PATEN, merupakan pembenahan peningkatan kualitas pelayanan kecamatan dalam rangka mewujudkan nilai-nilai/semangat tata kelola pemerintahan yang baik. Secara filosofis dan sosiologis, penyelenggaran PATEN berusaha mendekatkan pelayanan kepada masyarakat, yang mana kecamatan menjadi simpul pelayanan. Kecamatan dituntut bekerja secara sistematis merencanakan dan melaksanakan pelayanan kepada publik.

Kota Bandung suatu saat dapat melaksanakan kebijakan PATEN, dengan tetap mempertimbangkan bahwa pelimpahan kewenangan didasarkan pada tipologi kecamatan, skala, jenis pelayanan, dampak dan tingkatan tanggung jawab dari pelayanan yang diberikan. Bagaimanapun, baik buruknya pelayanan oleh Pemerintahan Kecamatan mencerminkan kualitas kinerja Pemerintah Daerah setempat. Kecamatan harus dijadikan tumpuan pelayanan publik mengingat banyak tugas dari perangkat daerah lainnya yang secara riil justru bisa dioperasionalisasikan karena adanya fungsi kewilayahan yang dimiliki kecamatan.

\section{DAFTAR PUSTAKA}

Arnaboldi, Michela, et.al. (2015). Performance Management in The Public Sector: The Ultimate Challenge. Journal of Financial Accountability and Management. Volume 31 (1), pg. 1-22

Mardani, Moh. Iskandar. (2011). Pelimpahan Kewenangan Bupati Dalam Otonomi Daerah (Kajian Pelimpahan Kewenangan Delegatif Bupati Kepada Camat di Kabupaten Parigi Moutong Propinsi Sulawesi Tengah). Jurnal Academica. Fisip Untad Volume 03 (1), hal. 547-563

Moenir, A.S. (1995). Manajemen Pelayanan Umum Indonesia. Bumi Aksara. Jakarta.

Moleong, Lexy J. (2005). Metodologi Penelitian Kualitatif. Bandung : PT. Remaja Rosdakarya

Ochojski, Artur, dan Marcin Baron. (2015). Innovation In Public Services: The Pursuit Of Economic Drivers. Journal of Economic and Management, Volume 19 (1), pg.173-180

Ratminto, Winarsih. (2007). Manajemen Pelayanan. Jakarta: Pustaka Pelajar

Undang-Undang Nomor 25 Tahun 2009 Tentang Pelayanan Publik.

Undang-Undang Nomor 23 Tahun 2014 Tentang Pemerintah Daerah

Peraturan Presiden Nomor 98 Tahun 2014 tentang Perijinan Tentang Usaha Mikro dan Kecil

Peraturan Menteri Dalam Negeri Nomor 4 Tahun 2004 Tentang Pedoman Pelayanan administrasi Terpadu Kecamatan (PATEN).

Permendagri Nomor 24 Tahun 2006 tentang Pedoman Penyelenggaraan Pelayanan Terpadu Satu Pintu.

Peraturan Daerah Kota Bandung Nomor 06 Tahun 2008 Tentang perubahan Atas Peraturan Daerah Kota Bandung Nomor 06 Tahun 2006 Tentang Pemekaran dan Pembentukan Wilayah Kerja Kecamatan Dan Kelurahan di Lingkungan Pemerintah Kota Bandung.

Peraturan Daerah Kota Bandung Nomor 18 Tahun 2011 tentang RTRW Kota Bandung Tahun 20112031.

Peraturan Walikota Bandung Nomor 185 Tahun 2015 tentang Pelimpahan Kewenangan Walikota Kepada Camat dan Lurah. 